\title{
Editorial
}

\section{Restoration and the Dilemma of Human Use}

Item: The cover story in this week's Newsweek (July 28,1986 ) is devoted to the ongoing problem of overuse in the national parks. On the cover, over a close-up photo of a grizzly bear, are emblazoned the words "Can we save our parks? The struggle between man and beast."

Item: On the same day this issue of Newsweek came into my hands, I walked past the site of a new prairie restoration project around a recently constructed desilting pond at the edge of the Arboretum. The prairie, now three years old, is a mass of yellow coneflowers intermixed with spikes of young blazing stars. On this particular hot, midsummer day, three volunteers were out in the prairie pulling weeds and piling them in big bundles along the street, just a few steps from a busy bus stop.

Question: What would happen if we put these two items together? Clearly we have a problem of overuse in the parks. But doesn't this other sort of activity suggest at least part of a solution?

The problem with much environmental thinking, it seems to me, is that it is too-well, environmental. That is it takes it for granted that the world, the rest of nature is something "out there" and that human beings are somehow outsiders, alienated from this other world.

One problem with this sort of thinking is that it is selectively anti-ecological-that is it emphasizes and celebrates relationships and interactions, the influence of species on each other, while setting up non-involvement by our species as a kind of ideal.

Another, more immediate and practical problem is that it assumes that human influence on nature is invariably harmful. In other words, so far as the rest of nature is concerned, it makes us not members or participants, but consumers.

In this view the best we can hope for, at least so far as pristine or "natural" nature is concerned, is no relationship at all. And even the most innocent activities-birding, say, or backpacking-manage to be only less harmful than really destructive activities such as mining or the dumping of chemical wastes.

Hence Newsweek's man against beast headline, which simply takes it for granted that people-all of us, including the most respectful vacationer-have interests that are fundamentally opposed to those of the rest of nature.

It seems to me, however, that the goings on at our desilting pond prairie suggest something quite different. Here we have folks hard at work, spending their vacation and retirement time working out in the hot sun, helping to put a piece of nature back together. This is quite different from the image of a horde of people using nature up, wearing it out, or "loving it to death."
These people are engaged in a relationship with nature that is active, participatory-and beneficial. This, it seems to me, is more than just scientific or ecologically sophisticated gardening. Rather it is nothing less than a ritual-I am tempted to say a sacrament-of reentry and reconciliation with nature.

And that might have important implications for the dilemma about the human use of nature in our parks and preserves.

Maybe this problem begins with that sense of alienation that runs through so much environmental thinking and that makes us think of ourselves as consumers of nature rather than participants in it. Maybe what we need is not less contact with the parks but a different kind of relationship with nature in general.

Suppose that instead of taking it for granted that we humans enter nature only as intruders or vandals, we tried to find ways to interact with nature-even "natural" nature-in a positive way. People clearly want contact with nature-that is what the crisis in the national parks is all about. But there are many ways of having contact with nature. There are activities such as birding and hiking that emphasize observation and appreciation; and there are others that imply a more active, yet positive kind of engagement and participation. One of these, of course, is ecological management and restoration.

Our prairie restorationists, for example, are getting a healthy dose of contact with nature. In fact they are coming much closer to nature than they are likely to get as visitors at a national park.

Maybe this will satisfy part of their need to visit Yellowstone, ultimately relieving some of the pressure on "natural" areas. And in any case, what a marvelous thing-instead of visiting some far-off place as a tourist, to participate in the making of a bit of nature in your own neighborhood-your habitat.

Perhaps in the future many of those who do visit the parks will actually participate in restoration and management programs, leaving the parks not worse than they found them but slightly better.

Utopian? Perhaps. Yet things like this do happen. Examples that come to mind are Earthwatch, which puts volunteers into the field to assist with research projects; and the Biosphere Reserve program which extends the idea of a park to include habitat for species, including human beings.

William R. Jordan III 